\author{
Сања Ж. ЂУРОВИЋ \\ Универзитет у Крагујевцу \\ Филолошко-уметнички факултет
}

Оригинални научни рад

Примљен: 28. 01. 2019.

Прихваћен: 14. 02. 2019.

\title{
НУЛТИ НАСТАВАК И НУЛТИ СУФИКС У СРПСКОМ ЈЕЗИКУ**
}

\begin{abstract}
Морфемска анализа речи захтева издвајање морфема и одређивање типа морфема. Нулта морфема је надређени термин и у морфемској анализи нулта морфема назива се и нулти наставак, а у творбеној анализи - нулти суфикс. Позиција нултог наставка тачно је одређена, док је позиција нултог суфикса много сложенија. У раду се дефинишу термини нулти наставак и нулти суфикс на основу граматика и литературе и коментаришу позиције у којима се бележе. У српском језику морфематика није много разматрана, али постоје радови који се баве овим питањима, нарочито о нултом суфиксу.
\end{abstract}

Кључне речи: морфематика, нулта морфема, нулти наставак, нулти суфикс.

1. Предмет рада је нулта морфема у морфемској и творбеној анализи, односно нулти наставак у морфемској и нулти суфикс у творбеној анализи. У литератури се често напоредо користе и термин нулта морфема, с једне стране као надређени термин за нулту позицију и у морфемској и у творбеној анализи, и с друге стране термини нулти наставак и нулти суфикс који су прилагођени типу анализе. Циљ рада јесте прецизно дефинисати и одредити место нулте морфеме у морфемској и творбеној анализи и на примерима показати шта означавамо истакнутим типовима морфема које се најчешће дефинишу одсуством обележја. Шире питање нултих вредности које је назначено овде неће бити предмет рада, већ само издвојена нулта морфема као флексијска (флективна) морфема и нулти суфикс као творбена морфема. Циљ анализе јесте јасно одвајање морфемске и творбене анализе и указивање на значај класификације типова морфема за морфологију. Терминолошки је јасно одређен систем морфема и субморфема у словенској лингвистичкој литерату-

\footnotetext{
*sdjurovic74@gmail.com

** Рад је настао у оквиру пројекта 178014 Динамика структура савременог српског језика, који финансира Министарство просвете, науке и технолошког развоја Републике Србије.
} 
ри, док се у србистици о морфематици мало писало. Недостатак литературе резултира и терминолошким проблемима ${ }^{1}$ и различитим приступима у конкретним морфемским и творбеним анализама 2 .

2. Питање нултих вредности одавно је покренуто. „Још је Панини у својој граматици санскрита уочио постојање нула морфеме. Међутим, појам нулте вредности широко се употребљава тек у XX столећу, нарочито у лингвистици нетрадиционалног типа. О. С. Ахманова, нпр. уводи овакве одреднице за нулте вредности: нулти члан, нулти афикс, нулти варијант фонеме, нулто значење, нулта категорија, нулта морфема, нулти показатељ, нулти везник, нулта флексија, нулта форма, синтагме" (Јовић 1977: 17). Јовићу није био циљ „списак категорија и феномена где се нулте вредности јављају, већ да размотри принципска питања" (Јовић 1977: 18).

Запажање које је за нас важно и у овом раду јесте: „Очигледно је, даље, да постоје извесне разлике између нултих вредности у систему деривације према нултим вредностима у морфолошком систему. Тако је бар у флексивним језицима" (Јовић 1977: 19). То подразумева јасну разлику између нултог наставка и нултог суфикса и разликовање морфемског и творбеног плана.

3. У граматикама српског језика и литератури не посвећује се довољно простора морфемама и типовима морфема, а тамо где се и помињу често долази до мешања нивоа морфемске и творбене анализе. Свакако је интересовање за нулти суфикс много веће, што је и очекивано знајући да се његова позиција констатује у великом броју твореница и да је сама творба речи развијенија дисциплина.

У Граматици Станојчић/Поповић користе се термини нулта морфема и нулти наставак за облик и убрајају се у граматичке морфеме (Станојчић/ Поповић 2008: 73). Разлог је разликовање суфикса и наставака и плана морфемске и творбене анализе те се каже: „Термин суфикс резервисан је за творбу (грађење) речи, термин наставак за облик резервисан је за морфологију" (Станојчић/Поповић 2008: 72). Термин нулти суфикс само се наводи у оквиру творбених морфема, али се о њему не расправља.

Значајан је рад И. Грицкат (1981) о именицама типа налет где се даје мноштво примера који су класификовани по ужим семантичким пољима и у овом раду користи се термин „нул-суфикс”. Рад Р. Маројевића „Српски и словенски нулти суфикс" (2012) веома је значајан за сагледавање дијахронијске перспективе и историјског развоја нултог суфикса.

Од новијих радова издвајају се два рада заснована на контрастивном методу у којима се анализира нулти суфикс у руском и српском језику (Лепојевић 2015 и 2016). „Нулти суфикс је формално неизражени показатељ творбеног значења мотивисане речи. Његово формално одсуство подједнако је важно као и присуство неког другог суфикса. [...] Поред тога, нулти суфикс има и категоријално значење: помоћу њега се реч преводи из једне врсте у другу или из једног типа промене у други са евентуалном променом

\footnotetext{
${ }^{1}$ Више о појмовима морфематике у: Ђуровић 2017.

${ }^{2} \mathrm{O}$ различитим приступима у морфемским и творбеним анализама биће речи у посебном раду.
} 
рода именице" (Лепојевић 2015: 224). Ипак, у овим радовима руски језик је примарни и често се мешају термини нулти суфикс и нулта морфема иако је истраживање у домену творбе речи.

4. Нулти наставак је „празно место” на крају речи које стоји у опозицији са осталим граматичким морфемима (наставцима) исте речи. Појмом нулта морфема или нулти наставак користимо се у морфемској анализи. Нулта морфема је флексијска (флективна) или граматичка морфема. „Граматичке морфеме не служе за стварање нових речи већ само за обележавање различитих облика једне те исте речи. Њихов ивентар је ограничен и лако их је набројати [...] Знаком ø обележава се такозвана нулта морфема, тј. „празно место” на крају коренске морфеме које стоји у опозицији са осталим граматичким морфемама исте речи [...]” (Мразовић/Вукадиновић 2009: 21). „Морфема може бити гласовно изражена [...] или гласовно неизражена. Гласовно неизражена морфема назива се нулта морфема" (Маројевић 2008: 215).

Често се у традиционалној граматици среће и појам нулте деклинације за непроменљиве речи.

Позиција нулте морфеме у морфемској анализи прецизно је одређена и бележимо је код:

a) именица мушког и женског рода које се завршавају на сугласник ${ }^{3}$ (нпр. јунак-ø, камен-ø, домаћин-ø, љубав-ø, радост-ø, младост-ø и сл.) и

б) код придева неодређеног вида (нпр. добар-ø, вредан-ø, златан-ø, срећан-ø и сл.).

5. Нулти суфикс је творбена морфема и означава непостојање суфикса у датој речи. Позиција нултог суфикса много је сложенија у односу на нулти наставак. Иако о нултом суфиксу има много више радова, што је и очекивано, често у литератури наилазимо на различита тумачења и бележења нултог суфикса. Дијахронијски и синхронијски приступ нултом суфиксу умногоме се разликују.

У литератури наилазимо и на колебања у вези са класификацијом именица са нултим суфиксом - да ли су просте (вез, говор) или сложене (изговор, договор, додир $)^{4}$. Сматра се да су ове именице настале безафиксним начином творбе или нултом афиксацијом. „Подвлачимо да овакво третирање разматраног начина творбе, тј. као деривације помоћу нултог суфикса, као полазиште узима синхронију, тј. језичко стање у датом моменту испитивања, што значи да приликом оваквих случајева синхронична творба не мора и не може трагати за у савременом језику ишчезлим вокалима ь и ь и сл.” (Анчић Обрадовић 1975: 13).

Бабић разликује - $\varnothing^{1}$ (мушког рода, као у додир) и - ${ }^{2}$ (женског рода, као у помоћ) (Бабић 1986: 29). Код Бабића наилазимо на констатацију да може доћи до мешања нултог суфикса и нултог наставка. „У скупини у којој

\footnotetext{
${ }^{3}$ Ту спадају и именице женског рода типа (-)мисао - мисл-и.

${ }^{4}$ Мисли се на сложене, а заправо се ради о префиксацији која се некада сматрала подврстом композиције.
} 
су се налазиле ријечи са нултим суфиксом могле су се наћи и нетворбене ријечи с нултим наставком: именице м. р. склонидбеног типа јелен и ж. р. и-склонидбе" (Бабић 1986: 283). Даље истиче да су неке нетворбене речи лако издвојене, а неке могу имати двојака решења. „Кад се има на уму творба именица нултим суфиксом осим граничних ријечи посебну тешкоћу задају првенствено оне именице које су у творбеној вези с непрефигираним глаголима, а не значе глаголску радњу" (Бабић 1986: 284). Бабић напомиње да проблеме задају и морфонолошке појаве јер основе имају различите промене и да творенице нису истог рода па предлаже увођење шест нултих суфикса (морфофонема), четири за м. р. и два за ж. р. разликујући оне који не изазивају никакве промене и оне који изазивају палатализацију, депалатализацију и десибиларизацију.

Р. Маројевић издваја - $\varnothing^{1},-\varnothing^{2}$, серију нултих а-суфикса, два нулта суфикса на -о и два нулта суфикса на -е (Маројевић 2012: 637-651).Често је тешко разликовати када је реч заиста о суфиксу, а када о наставку, али Маројевић аргументовано тумачи конкретне примере и указује на пропусте у литератури. ,[...] помоћу нултог суфикса за творбу именица мушког рода прве деклинације (суфикс -ø1) изведене су именице типа залог, а помоћу нултог суфикса за творбу девербативних именица женског рода прве деклинације (суфикс $\left.-\mathrm{a}^{3}\right)$ - именице типа залога. И суфикс $-\mathrm{a}^{3}$ је нулти, као и суфикс $-\varnothing^{1}$ : разлика је у томе што овај први твори именице које у номинативу сингулара имају материјално изражен наставак $-a$, а овај други - именице које у номинативу сингулара имају нулти наставак (за епоху пре губљења полугласника рекли бисмо за њега: суфикс -ъ, иако је и тада био нулти)" (Маројевић 2012: 647).

Синхронијски посматрано сложили бисмо се са Клајном да је појам нултог суфикса неопходан на крају речи и да увођење варијација -øа, -øо, -øе осликава старија стања и да није погодан за синхронијску анализу (нпр. супруг-ø-супруг-ø- $а$ ).

Специфичност нултог суфикса у односу на друге суфиксе одликује се и одсуством бинарне структуре, односно једноморфемске је структуре. То констатује и Г. Штасни: „Наиме, у свим суфиксалним творбеним формантима, осим у нултом, видљива је бинарна структура, што значи да они истовремено садрже творбену и граматичку морфему (-иц- $a$; ишт-e). У нултом суфиксу семантичка и морфолошко-категоријална димензија коегзистирају и не могу се формално сегментирати. Деривати са нултим суфиксом према својој структури блиски су или су веома налик простим речима, па се управо из тих формалних разлога са њима често и поистовећују” (Штасни 2010: 93).

5.1. Критеријуми у бележењу нултог суфикса полазе од етимологије и семантике. Бабић критеријуме преузима од руских дериватолога па у односу именица : глагол сматра изведеном ону реч која има сложенију фонемско-морфемску структуру.

5.1.1. Нулти суфикс - $\varnothing^{1}$ (мушког рода) имамо у:

a) именицама изведеним од простих глагола (девербативи) који, по правилу, означавају глаголску радњу, типа: лов, лет, трк, мук, плач, 
пролаз, рад, труд, раст, пост, спор, кашаљ, шапат итд. (Клајн 2003: 214).

„Ако се изузму три изведенице од придева [...] све остале изведенице на -ø1 (мушког рода) имају глаголску основу. То су у мањем броју случајева прости глаголи, много чешће префиксирани, а такође глаголи у другом делу сложеница” (Клајн 2003: 214).

Код ових именица често има различитих тумачења. Тако Клајн именицу брод сматра простом са синхронијског становишта, а Маројевић изведеницом са нултим суфиксом од глагола бродити. Р. Маројевић сматра и да је пароброд настала комбинованом творбом (пловни објекат који броди), а не композицијом како је код Клајна. „Савремено језичко осећање друкчије интерпретира именицу - као реч која је настала само композицијом, а која је мотивисана синтагмом брод на пару. Промена се зове декорелација (врста и распоред морфема остали су исти, али је измењен однос мотивације и природе последњих двеју морфема у сложеној основи: |брод| се осећа као именички а не као глаголски корен, нулти суфикс - ${ }^{1}$ не учествује у творбеном процесу, није формант именице пароброд, али остаје у морфемској структури, као творбени формант помоћу којег је настала друга творбена база, именица брод" (Маројевић 2005: 705).

Код ове групе примера са нултим суфиксом често се поставља питање мотивације и колико је она до данас очувана у многим примерима. И. Грицкат истиче да су ово „примери поименичавања, а зна се да је оно у словенским језицима, по правилу, везано за суфиксе. У овом случају јавља се тзв. нул-суфикс, који је равноправан са осталим суфиксима, мада, нарочито у старијим граматикама, често измиче пажњи" (Грицкат 1981: 103). Она сматра да је налет у погледу творбе и значења исто што и налетање, опрост исто што и onpoштај. Истиче да код неких речи искрсава недоумица да ли су то изведенице од глагола или су послужиле као мотивне речи за извођење нових глагола. Када се у другом делу нађу морфеме које не живе као самосталне именице, у таквим случајевима девербативно порекло је евидентно нпр. до-пуст, по-вој и сл.

Да ли је трк настало од трчати или обрнуто, да ли је траг од тражи$m u$ или обрнуто? И. Грицкат каже да се на основу етимолошких проучавања могу наћи сигурнији одговори, али да у науци и даље остају општеприхваћене непознанице. Принципијелно се може говорити да су ове именице у етимолошкој вези са глаголима, али не представљајући обавезно ни њихов накнадни продукт ни њихову мотивну реч (Грицкат 1981: 105);

б) именицама изведеним од глагола са префиксима (Грицкат 1981: 106):

- $\quad$ nomina actionis - (-)лет; полет, узлет (у односу на летење, мање указује на трајност радње)

- nomina acti - Hanad, ynad

- nomina resultativa - вез, савез

- nomina loci - изведенице од глагола на -лазити (улаз, излаз, прелаз, пролаз); апстрактне: размак, домет; специфичног значења: отвор, затвор, забран, довод, одрон и сл. Забран је данас семантички удаљено од забранити 
- nomina istrumenti - доглед, повез, повој, оклоп, омот, украс, накит, зачин, оков, премаз итд.

- nomina agentis - пребег, ускок.

„У овој области хијерархија значења и блискост семантичких прелива не само што су променљиве и танане, него често и у правом смислу неухватљиве. Лексикографија решава та питања од случаја до случаја, остајући пред њима понекад готово немоћна".

Изведенице на нулти суфикс могу постати и независне од глагола који им је у основи. Нпр. реч залив нема никакве везе са заливати, допис нема везе са дописивати (Клајн 2003: 216).

в) Сложенице 5 са нултим суфиксом су изузетно продуктивне по моделу именица + глагол. У другом делу сложенице имамо глаголску основу која се често поклапа са девербативном именицом на консонант типа: водовод, гасовод, иевовод, нафтовод, бродолом, водомер, струјомер, блатобран, сунияобран, месојед, биљојед, месождер, људождер, стрводер, добротвор, миротвор, рукопис, правопис, летопис, бакрорез, дрворез, ватромет, ногомет, рукомет, каменолом, бродолом, костолом, путоказ, родољуб, сунцокрет и сл. У анатомским терминима: жучовод, јајовод, мокраћовод (Клајн 2002: 53). „Вреди запазити да је глаголска основа увек једносложна. [...] Из наведених примера може се закључити да је семантика ових сложеница веома разнолика. Многе од њих означавају оруђа, справе, уређаје [...] али и радње и збивања (землотрес, ватромет), резултате радње (бакрорез, летопис), средства за обављање одређених радњи (мишомор, коломаз), људска бића (богослов, главос(j)ек, родољуб), биљке (сунцокрет, ладолеж) и друго” (Клајн 2002: 56).

Као окрњене глаголске основе у другом делу сложенице јављају се: -вод, -мер, -бран, -јед, -рез, -дер, -твор, -пис, -мет, -каз, -крет и сл. Иако их И. Клајн убраја међу сложенице са нултим суфиксом издвојени примери спадају у сложено-суфиксалну творбу: вод-о-мер-ø, суни-о-крет-ø и сл.

5.1.2. Нулти суфикс - $\varnothing^{2}$ (женског рода) данас је непродуктиван и број примера је мали. „За творбу именица ж. р. нултим суфиксом може се с великом сигурношћу рећи да је неплодна јер провјеравања показују да послије 1865. нема нових твореница. Прве потврде из 1860. и касније имају ове ријечи: обавијест, припомоћ, наговијест, цваст” (Бабић 1986: 302).

И. Клајн наводи следеће примере: „Од простих глагола су можда само лаж, моћ, чар и мисао (не рачунајући застареле облике као скрб или жуд). Од префиксалних глагола су замисао, помисао, намисао, примисао, помоћ, uсnомоћ (вероватно и припомоћ, док бисмо немоћ сматрали негацијом од моћ, пре него изведеницом од негираног глагола не моћu), nочасm, nрuчест, обав(uј)ест (претежно хрватски), пропов(иј)ед, зараван.

Посебну групу чине речи у којима нулти суфикс долази не на глаголску основу него на крњи инфинитив. Од простих глагола ту спада бum, можда и

\footnotetext{
${ }^{5}$ У литератури се називају сложенице, али су то најчешће примери сложено-суфиксалне творбе јер увек на крају имамо издвајање нултог суфикса.
} 
иваст; од префиксалних добит, забит (од глагола забити забудем 'заборавити', данас очуваног само у дијалектима) [...]

Од придева су млађ, дуж, нејач, вероватно и жеђ [...] Од редног броја је четврт. Једина обичнија сложеница са $-\varnothing^{2}$ изгледа да је благодат (Клајн 2003: 217-2018).

Са синхронијског становишта јасно је уочити окрњене глаголске основе у другом делу творенице где, по правилу, бележимо нулти суфикс. Неопходно би било објаснити етимологију и мотивациону везу именица типа мисао, лаж и сл., јер би, синхронијски, логичније било да се ради о простим именицама.

6. Након проведене анализе може се закључити да у терминолошком смислу у литератури треба уједначити да ли је нулта морфема надређен појам нултом наставку и нултом суфиксу или употреба термина нулта морфема и нулти суфикс јасно осликавају нивое анализе (морфемску и творбену). Управо се у литератури срећу различита решења. Шире теоријско одређење типова морфема умногоме би олакшало и морфемске и творбене анализе. Јасно одвајање дијахронијске и синхронијске анализе појаснило би статус издвојених морфема у синхроној перспективи. На основу литературе у савременом српском језику говоримо о два нулта суфикса (-ø - $\varnothing^{2}$ (женског рода)) с обзиром на непогодност увођења варијација -øа, -øо, -øе које осликавају старија стања и имају циљ раздвајања творбене и граматичке морфеме.

Издвајање нултог наставка у морфемској анализи јасно је одређено, док је позиција нултог суфикса доста сложенија и захтева шира истраживања. Неспорна позиција нултог суфикса - $\varnothing^{1}$ у творбеној анализи јесте код именица изведених од простих глагола (лов, лет, трк, рад и сл.), код именица изведених од префиксираних глагола (повез, полет, повој и сл.) и код твореница које у другом делу имају окрњене глаголске основе (водовод, водомер, сунцүокрет и сл.), што је веома продуктиван творбени модел. Позиција нултог суфикса - $\varnothing^{2}$ јавља се, најчешће, код твореница које имају окрњене основе у другом делу творенице (добит, забит и сл.) и код именица које су у мотивној вези са глаголом од кога су изведене.

Ирена Грицкат истиче да је грађење префиксираних именица са нул-суфиксом одговарало српскохрватском творбеном потенцијалу. Зато су такве именице скупљане и стављане у задате терминолошке спискове и нису имале баш срећну судбину. Девербативне именице уносе аспект и дијатезу у значења гл. радњи и богато развијају разнолика значења (Грицкат 1981: 133).

Све изнето показује да је неопходно опширније и детаљније анализирати творенице са нултим суфиксом како бисмо имали реалан увид колико су ове именице продуктивне, да ли представљају старији лексички нанос или има и нових твореница са нултим суфиксом које настају по продуктивним моделима. 


\section{ЛИТЕРАТУРА}

Анчић 1975: Марија Анчић Обрадовић, Суфиксална творба именица помоћу нулте суфиксације, Кюижевни језик, 4/1-2, 7-18.

Белић 1999: Александар Белић, Историја српског језика: фонетика, речи са деклинацијом, речи са конјугащијом, Изабрана дела Александра Белића, т. 4, Београд: Завод за уџбенике и наставна средства.

Бутакова 2012: Л. О. Бутакова, Морфемика и словообразование современного русского языка, Москва.

Бабић 1991: Stjepan Babić, Tvorba riječi u hrvatskom književnom jeziku, drugo izdanje, Zagreb: HAZU.

Грицкат 1981: Ирена Грицкат, О именицама типа налет у српскохрватском језику, Зборник Матице српске за филологију и лингвистику, 24/1, 101-134.

Ђуровић 2017: Сања Ђуровић, Основни појмови морфематике српског језика, Зборник са Међународне научне конференције Словенска терминологија данас, (ур. П. Пипер, В. Јовановић), Београд: САНУ - Институт за српски језик САНУ, 213-229.

Ивић 1961/1962: Милка Ивић, Један проблем словенске синтагматике, Јужнословенски филолог, XXV, 137-151.

Јовић 1973: Душан Јовић, Методолошке претпоставке изучавања морфонематике, Јужнословенски филолог, XXX/1-2, 347-351.

Јовић 1977: Душан Јовић, О нултим вредностима у језичкој структури, Јужнословенски филолог, XXXIII, 17-21.

Клајн 2002: Иван Клајн, Творба речи у савременом српском језику. Први део: слагање и префиксација, Београд: Завод за уџбенике и наставна средства, Институт за српски језик САНУ - Нови Сад: Матица српска.

Клајн 2003: Иван Клајн, Творба речи у савременом српском језику. Други део: суфиксација и конверзија, Београд: Завод за уџбенике и наставна средства, Институт за српски језик САНУ - Нови Сад: Матица српска.

Кристал 1999: Dejvid Kristal, Enciklopedijski rečnik moderne lingvistike, Beograd: Nolit.

Лепојевић 2015: Јелена Б. Лепојевић, Нулти суфикс као творбени формант код двотематских именица, Филолог, часопис за језик, књижевност $и$ културу, VI, Бања Лука: Филолошки факултет, 223-232.

Лепојевић 2016: Јелена Б. Лепојевић, Нулти суфикс као творбени формант код двотематских придева, Филолог, часопис за језик, књижевност $и$ културу, VII, Бања Лука: Филолошки факултет, 76-87.

Маројевић 2005: Радмило Маројевић, Творба речи у савременом српском језику Ивана Клајна (1), (приказ), Српски језик, 10/1-2, 687-779.

Маројевић 2008: Радмило Маројевић, Српски језик данас, Београд - Бања Лука: Бард-фин - Романов.

Маројевић 2010: Радмило Маројевић, Творба двотематских ријечи (Студија случаја: сунцокрет), Гласник Одјељења умјетности 28, Подгорица: ЦАНУ, 25-33. 
Маројевић 2012: Радмило Маројевић, Српски и словенски нулти суфикс, Зборник радова са 14. међународне конференције Комисије за творбу речи при МКС-у, Творба речи и њени ресурси у словенским језицима, 637-652.

Мразовић/Вукадиновић 2009: Pavica Mrazović, Zora Vukadinović, Gramatika srpskog jezika za strance, Sremski Karlovci - Novi Sad: Izdavačka knjižarnica Zorana Stojanovića.

Симић 1977: Радоје Симић, Граматичка морфема као обележје реченичне структуре и питање њеног садржаја, Зборник радова поводом 70. година Јована Вуковића, Сарајево, 353-357.

Симић 1984: Радоје Симић, Природа језичког знака са гледишта теорије релативитета, Научни састанак слависта у Вукове дане, 13/1, 227-245.

Симић 2001: Радоје Симић, Српска граматика I, Београд: МХ Актуел.

Симић 2005: Радоје Симић, Неке недоумице око морфологије глагола, $\mathrm{Cpn-}$ ски језик, 10/1-2, 75-132.

Соколова и др. 1999: M. Sokolová, G. Moško, F. Šimon, V. Benko, Morfematický slovník slovenčiny, Prešov: Náuka.

Станојчић/Поповић 2008: Живојин Станојчић, Љубомир Поповић, Граматика српскога језика за гимназије и средюе школе, Београд: Завод за уџбенике и наставна средства.

Штасни 2010: Гордана Штасни, Мотивациони смерови у деривационим процесима, Зборник Матице српске за филологију и лингвистику, LIII/2, 89-97.

Штасни 2017: Гордана Штасни, Морфемска и творбена анализа - проблемски приступ, Прилози настави српског језика и књижевности, VI, Бања Лука: Друштво наставника српског језика и књижевности Републике Српске, 97-112.

Sanja Z. Đurović

THE ZERO ENDING AND ZERO SUFFIX IN SERBIAN

Summary

To analyze morphemes in a word it is necessary to identify the morphemes and determine their type. The zero (or null) morpheme is a superordinate term. The zero morpheme is also called the zero ending in morpheme analysis. In word formation analysis the term zero suffix is applied. This paper examines the definitions of the terms zero ending and zero suffix in grammars and literature, and the positions in which these are observed. Although morphemics has not been much analyzed in the Serbian language, some papers have dealt with these issues, especially with the zero suffix.

While it is clear how to identify the zero ending in morpheme analysis, the position of the zero suffix is much more complex and requires further research. In word formation analysis, the zero suffix is undeniably found in nouns derived from simple verbs (e.g. lov, let, trk, rad etc), in nouns derived from verbs with prefixes (e.g. povez, polet, povoj etc) and in compound nouns whose second part is the reduced infinitive base (e.g. vodovod, vodomer, suncokret etc.), which is a very productive model of word formation.

Key words: morphemics, zero morpheme, zero ending, zero suffix. 